\title{
Traditional faith healers as referral sources: A hospital- based descriptive study
}

\author{
Thapa DK ${ }^{1}$, Lamichhane $\mathbf{N}^{2}$, Subedi $\mathbf{S}^{3}$
}

1. Associate Professor, Department of Psychiatry, Gandaki Medical College, Pokhara, Nepal 2. Associate Professor \& Head, Department of Psychiatry, Gandaki Medical College, Pokhara, Nepal 3. Associate Professor, Department of Psychiatry, Universal College Of Medical Sciences, Bhairahawa, Nepal

E-mail *Corresponding author : ddthapa@hotmail.com

\begin{abstract}
Introduction: Mental illnesses are commonly linked with a higher disability and burden of disease than many physical illnesses. But despite that fact, it is a general observation that a majority of patients with mental disorder never seek professional help. To elaborate further, the widely prevalent magico-religious beliefs associated with mental illness and lower literacy, poses significant social obstacles in seeking appropriate health care for psychiatric patients. In general, mental illness is seen as related to life stresses, social or family conflicts and evil spirits and the concept of biological causes of mental illness is rare even among the educated. The idea that illness and death are due to malevolent spirits is common notion that is shared practically by all level of society from the so-called primitive to modern industrialized societies, thus indicating the strong influences of cultural background. When there is a magico-religious concepts of disease causation, there is tendency to consult indigenous healers. Therefore, the patients with mental illness often either visit or are taken to faith healers by their relatives. The objective of the study was to determine the various psychiatric cases that were referred by the traditional faith healers to the authors.
\end{abstract}

Material And Method: This is a cross- sectional, hospital- based descriptive study, conducted at the Psychiatric outpatient department of Pokhara Om Hospital, Pokhara, Kaski, Nepal for the period of one year, from June 2016 to May 2017. The total of 35 cases, referred by the traditional faith healers was included in the study. Subjects of any age, any gender, any literacy level, any caste, from any locality and religious background were included in the study after their consent. Subjects who refused to consent were not included in the study. The psychiatric diagnosis was based on the complete history and examination and ICD-10 DRC criteria.

Results: Though the sample size is small, it is interesting to note that patients with various kinds of mental disorders were referred by traditional faith healers. There were patients suffering from neurotic disorders, psychotic disorders, mood disorders, seizure, substance use disorder, intellectual disability etc seeking the treatment from traditional faith healers. Among the cases referred, predominantly were female and neurotic cases. Most patients were educated.

Conclusion: The study shows that patients with various mental disorders visit traditional faith healer. This area surely requires further in-depth look as traditional faith healers can be an important source of referral of psychiatric patients.

Keywords: Mental disorder; Faith Healers; Female; Neurotic

\section{INTRODUCTION}

The World Health Organization has noted that one in every four people is affected by a mental disorder at some stage of life. ${ }^{1}$ Six neuropsychiatry conditions; unipolar depressive disorders, alcohol use disorders, schizophrenia, bipolar affective disorder, Alzheimer's and other dementias and migraine have figured in the top 20 causes of disability in the world. ${ }^{2}$ But despite the mentioned facts, it is a general observation that a majority of patients with mental disorder never seek professional help and most of them utilize the help of unqualified medical practitioners, faith healers and so on. The non- 
availability of mental health services, penury, stigma, and superstitions associated with mental disorders, coupled with the unwillingness or inability of families to care for their mentally ill relatives, appear to be the main contributory factors. ${ }^{3}$ Apart from a lack of awareness about treatment services, a large proportion of psychiatric patients do not attend any health facility due to the distance, the fear of the stigma associated with treatment and some thought the treatment would be expensive. When it comes to stigma, a number of patients from rural areas report the fear of stigmatization and isolation from the community if the psychiatric illness was disclosed, therefore causing the psychiatric patients first seek the help of various sources prior to attending a psychiatric health facility. ${ }^{4}$ To state further, the widely prevalent magicoreligious beliefs associated with mental illness and lower literacy, poses significant social obstacles in seeking appropriate health care for psychiatric patients. ${ }^{4}$ There are people who do prefer black magic as the first line of treatment for mental illness ${ }^{5}$ and ascribing illness to external malevolent influences like spirits, gods, deities etc is a very widespread belief. ${ }^{6}$ In general mental illness is seen as related to life stresses, social or family conflicts and evil spirits 7 and the concept of biological causes of mental illness is rare even among the educated. ${ }^{6}$ The idea that illness and death are due to malevolent spirits is common notion that is shared practically by all level of society from the socalled primitive to modern industrialized societies, thus indicating the strong influences of cultural background. When there is a magicoreligious concepts of disease causation, there is tendency to consult indigenous healers. ${ }^{8}$

Local and community belief in such phenomena appeared to be a factor in influencing the decision to seek magico-religious treatment. 9,10 In the study by Sapkota $\mathrm{N}$ et al, the main treatment offered by the traditional healers were performing puja/rituals/jhad-phoonk, sacrifices of chicken, eggs, goat), horoscope reading and palm reading. ${ }^{11}$ Other treatments are done with the use of ashes, mullets and holy water. ${ }^{4}$ Only a limited proportion of patients with psychiatric disorders attend the healthcare facilities, and that too when the condition becomes severe. Treatment from unqualified medical practitioners and faith healers is a common practice, and is attributable to the delay in proper treatment. ${ }^{4}$ In Nepal, such practice is prevalent almost everywhere both in rural and urban setting and many faith healers believe that there is no treatment for psychiatric illness except the traditional approaches. ${ }^{12}$

Since the patients with mental illness often either visit or are taken to faith healers by their relatives, this study was conducted out of curiosity to determine the various psychiatric cases that were referred by them to the authors.

\section{MATERIAL AND METHOD}

This is a cross- sectional, hospital- based descriptive study, conducted at the Psychiatric outpatient department of Pokhara Om Hospital, Pokhara, Kaski, Nepal for the period of one year, from June 2016 to May 2017. The total of 35 cases, referred by the traditional faith healers was included in the study. Three faith healers, involved were known to the authors. Pokhara Om Hospital is one of the oldest private hospitals in the city operating since the last 19 years. Both the authors have been providing Psychiatry service there since almost 10 years on regular basis. Subjects of any age, any gender, any literacy level, any caste, from any locality and religious background were included in the study after their consent. Subjects who refused to consent were not included in the study. The psychiatric diagnosis was based on the complete history and examination and ICD- 10 DRC criteria. The needful data were collected by using the semi- structured performa designed for the study. The objective of the study was to determine the various psychiatric cases that were referred by the traditional faith healers to the authors.

\section{RESULT}

The total number of patients involved in the study was 35 . The ages of the subjects ranged from 10 years to 55 years, with the mean age of 28.54 years with SD of 10.60. Females were dominant in numbers, comprising of 22 cases (62.9\%). All cases were Hindu and from the local district of Kaski $(n=25,71.42 \%)$ and near by district Synagjya $(n=10,28.58 \%)$. Majority were Chhetri/ Brahmins (51.42\%), followed by the castes of Mongolian origins (34.29\%) followed by other castes $(14.29 \%)$. Most of the subjects ( $\mathrm{n}=$ $28,80 \%$ ) were literates. 
The study showed that, the most cases that were referred by the traditional faith healers belonged to category of Neurotic, Stress related and Somatoform Disorder ( $n=20,57.14 \%)$, followed by cases belonging to category of Mood Disorder $(n=6,17.14 \%)$, then cases belonging to category of Schizophrenia and Schizotypal and Delusional Disorder $(n=4,11.43 \%)$ and other cases $(n=5,14.29 \%)$.

Among the Neurotic, Stress related and Somatoform Disorder category; 8 were cases of Anxiety Unspecified, 3 of Generalized Anxiety Disorder, 2 of Panic Disorder and 7 of Somatoform Disorder. From the category of Mood Disorder, 5 cases were of Severe Depression with Psychotic symptoms and 1 of Bipolar Affective Disorder. From the category of Schizophrenia and Schizotypal and Delusional Disorder, there was 1 case of Acute and Transient Psychotic Disorder and 3 cases of Schizophrenia. Among the other group, there were 2 cases of Seizure Disorder, 2 cases of Intellectual Disability and 1 case of Alcohol Dependent Syndrome with Induced Psychosis. (See Table)

The salient findings of the study were that among the cases referred, predominantly were female and neurotic cases and most were educated.

Table 1: Socio-Demographic Distribution of Subjects

\begin{tabular}{|c|c|c|}
\hline \multicolumn{3}{|l|}{ Gender distribution: } \\
\hline Male & $13(37.1 \%)$ & \multirow{2}{*}{$\begin{array}{c}\text { Tota } \\
35\end{array}$} \\
\hline Female & $22(62.9 \%)$ & \\
\hline \multicolumn{3}{|c|}{ Literacy distribution: } \\
\hline Illiterates & $7(20 \%)$ & \multirow{2}{*}{$\begin{array}{c}\text { Total } \\
35\end{array}$} \\
\hline Literates & $28(80 \%)$ & \\
\hline \multicolumn{3}{|l|}{ Caste distribution: } \\
\hline Chhetri/Brahmin & $18(51.42 \%)$ & \multirow{3}{*}{$\begin{array}{c}\text { Total } \\
35\end{array}$} \\
\hline Mongolian Origins & $12(34.29 \%)$ & \\
\hline Others & $5(14.29 \%)$ & \\
\hline \multicolumn{3}{|c|}{ Locality distribution: } \\
\hline Kaski & $25(71.42 \%)$ & \multirow{2}{*}{$\begin{array}{c}\text { Total } \\
35\end{array}$} \\
\hline Syangja & $10(28.58 \%)$ & \\
\hline
\end{tabular}

Table 2: Distribution of Subjects based on Diagnosis

\begin{tabular}{|c|c|c|c|}
\hline $\begin{array}{l}\text { Diagnostic } \\
\text { Group }\end{array}$ & $\begin{array}{l}\text { ICD } 10 \\
\text { Diagnosis }\end{array}$ & $\begin{array}{r}\text { Total } \\
(\%) \\
\end{array}$ & \\
\hline \multirow{4}{*}{$\begin{array}{l}\text { Neurotic, } \\
\text { Stress related } \\
\text { And } \\
\text { Somatoform } \\
\text { Disorder }\end{array}$} & $\begin{array}{l}\text { Anxiety } \\
\text { Unspecified }\end{array}$ & $\begin{array}{r}8 \\
(22.9 \%)\end{array}$ & \multirow{4}{*}{$\begin{array}{c}\mathrm{n}=20 \\
57.14 \%\end{array}$} \\
\hline & $\begin{array}{l}\text { Generalized } \\
\text { Anxiety } \\
\text { Disorder }\end{array}$ & $\begin{array}{c}3 \\
(8.6 \%)\end{array}$ & \\
\hline & $\begin{array}{l}\text { Panic } \\
\text { Disorder }\end{array}$ & $\begin{array}{r}2 \\
(5.7 \%)\end{array}$ & \\
\hline & $\begin{array}{l}\text { Somatoform } \\
\text { Disorder }\end{array}$ & $7(20 \%)$ & \\
\hline \multirow[t]{2}{*}{$\begin{array}{c}\text { Mood } \\
\text { Disorder }\end{array}$} & $\begin{array}{l}\text { Depression } \\
\text { with } \\
\text { Psychotic } \\
\text { symptoms }\end{array}$ & $\begin{array}{r}5 \\
(14.3 \%)\end{array}$ & \multirow[t]{2}{*}{$\begin{array}{c}\mathrm{n}=6 \\
17.14 \%\end{array}$} \\
\hline & $\begin{array}{l}\text { Bipolar } \\
\text { Affective } \\
\text { Disorder }\end{array}$ & $\begin{array}{r}1 \\
(2.9 \%)\end{array}$ & \\
\hline \multirow[b]{2}{*}{$\begin{array}{c}\text { Schizophrenia } \\
\text { and } \\
\text { Schizotypal } \\
\text { and } \\
\text { Delusional } \\
\text { Disorder }\end{array}$} & Schizophrenia & $\begin{array}{r}3 \\
(8.6 \%)\end{array}$ & \multirow{2}{*}{$\begin{array}{c}\mathrm{n}=4 \\
11.43 \%\end{array}$} \\
\hline & $\begin{array}{l}\text { Acute and } \\
\text { Transient } \\
\text { Psychotic } \\
\text { Disorder }\end{array}$ & $\begin{array}{r}1 \\
(2.9 \%)\end{array}$ & \\
\hline \multirow{3}{*}{ Others } & $\begin{array}{l}\text { Seizure } \\
\text { Disorder }\end{array}$ & $\begin{array}{r}2 \\
(5.7 \%)\end{array}$ & \multirow[t]{3}{*}{$\begin{array}{c}\mathrm{n}=5 \\
14.29\end{array}$} \\
\hline & $\begin{array}{l}\text { Intellectual } \\
\text { Disability }\end{array}$ & $\begin{array}{r}2 \\
(5.7 \%)\end{array}$ & \\
\hline & $\begin{array}{l}\text { Alcohol } \\
\text { Dependence } \\
\text { Syndrome } \\
\text { with Induced } \\
\text { Psychosis }\end{array}$ & $\begin{array}{r}1 \\
(2.9 \%)\end{array}$ & \\
\hline
\end{tabular}

\section{DISCUSSION:}

Despite high prevalence of mental disorders and higher disability and burden of disease associated with them, 1,2 it is a general observation that a majority of patients with mental disorder never seek professional help and most of them utilize the help of unqualified medical practitioners, faith healers etc. ${ }^{3}$ In the Indian study by Lahariya C et al, only $9.2 \%$ of the patients consulted a psychiatrist as the first helping agency, while majority of the cases first consulted faith healers. ${ }^{4}$

In our study, all the cases enrolled in the study had been to traditional faith healers as they were all referred to the authors by them. It is 
interesting to note that patients with various kinds of mental disorders have sought their help. Though the sample size is only 35 , we can see the patients suffering from neurotic to psychotic disorder, mood disorder, seizure, substance use disorder and intellectual disability seeking the help of traditional faith healers. When there are people; who prefer black magic as the first line of treatment for mental illness, 5 people who ascribe illness to external malevolent influences of spirits, gods, deities etc 6 and people who believe in the magicoreligious concepts of disease causation, there is tendency to consult indigenous healers. ${ }^{8}$ On top of that, since the concept of biological causes of mental illness is rare even among the educated people, ${ }^{6}$ it is likely that traditional faith healers become the first source of any form of treatment for the suffers and their families. Therefore, leaving aside the illiterates and those from rural settings, it is a fact that even the educated and those from the urban setting do seek out traditional form of treatment. It is possible that the fear of stigmatization and isolation from the community if the psychiatric illness was disclosed can cause the psychiatric patients to first seek the help of various sources prior to attending a psychiatric health facility. In the Indian study by Lahariya C et al, $73 \%$ of patients delayed health seeking due to the fear of stigma. 4

Though times are changing, methods of treatment sought are largely determined by the prevalent cultural beliefs. Every part of society is effected to some degree by the culture and traditional values. In the study by Sapkota $\mathrm{N}$ et $\mathrm{al}$, authors were surprised to find that $80 \%$ of the patients were brought after many weeks of illness when the duration of their journey to proper psychiatry centre was less than $12 \mathrm{hrs}$ and about an hour in some cases. This finding suggests the prevalent ignorance of psychiatric illness even in urban settings and the firm belief in faith healers. ${ }^{11}$

The presence and the services of traditional faith healers can not be simply ignored in the society. Many factors play roles when it comes to any decision making like seeking treatment. Those factors can be non-availability of mental health services, stigma, superstitions associated with mental disorders, the unwillingness or inability of families to care for their mentally ill relatives.
The study done by Neki J.S (1973) $)^{13,14}$ revealed that $80 \%$ of mentally ill persons consulted the traditional faith healer before arriving at a psychiatric clinic. Similarly in the study by Sapkota $\mathrm{N}$ et al, about $82 \%$ has sought help from traditional faith healers. ${ }^{11}$ It has been found that, the traditional healers, while dealing with psychiatric patients, often hide their inability to understand and treat these disorders and attribute them to supernatural causes, further enhancing the misbeliefs of these patients. 4

A study on the treatment of psychiatric disorders in India observed that in view of the paucity of facilities, $80 \%$ of the population had to depend on indigenous treatments consisting of Ayurvedic and Unani systems of medicine, religious treatments consisting of prayers, fasting, and so on, as also various witchcrafts and magical rituals. ${ }^{15}$

But in our setting where though many faith healers used to believe that there is no treatment for psychiatric illness except the traditional approaches, it is hopeful sign to see them referring the cases of mental disorders, though small in numbers, to mental health experts. This area surely requires further in-depth look as traditional faith healers can be an important source of referral of psychiatric patients in developing society like ours. When the safe motherhood and hospital delivery program can be initiated and run in the country, the authors believe that a similar push can be done so in the care of mentally ill patients.

\section{CONCLUSION:}

The study shows that patients with various mental disorders visit traditional faith healer. This area surely requires further in-depth look as traditional faith healers can be an important source of referral of psychiatric patients in developing society like ours.

\section{ACKNOWLEDGEMENT: None}

\section{CONFLICT OF INTEREST: None}

\section{REFERENCES:}

1. Mental health: New understanding, New hope: World Health Report 2001.Geneva: World Health Organization; 2001. Geneva: World Health 
Organization; 2001. World Health Organization; pp. 09-24.

2. Murray CJL, Lopez AD. Mortality by cause for eight regions of the world: Global Burden of Disease Study. Lancet. 1997;349:1269-76. [PubMed]

3. Rogler LH, Cortes DE. Help-seeking pathways: A unifying concept in mental health care. Am J Psychiatr. 1993;150:554-61. [PubMed]

4. Pathway of care among psychiatric patients attending a mental health institution in central India

5. Chandrakant Lahariya, Shyam Singhal, Sumeet Gupta and Ashok Mishra; Indian I Psychiatry. 2010, OctDec; 52(4): 333-338

6. Varghese A, E Beig A. (1974). Public Attitudes towards Mental Illness - The Velore study. Indian Journal of Psychiatry, 16, 8-18.

7. Regmi SK, Pokharel A., Ojha S.P. et al (2004) Nepal: Mental Health Country Profile. International Review of Psychiatry 16:142-9.

8. Acharya K, (1998). Knowledge, attitudes and practice of mental illness in a village population Ph D. thesis Kathmandu, Tribhuvan University

9. S.N Breckenridge $M D$, and MAC Breckenridge MD: $\mathrm{Ph}$ D. Department of Human services, East. Country Mental Health Clinic Multnomah Country, Portland, Oregon. Indigenous healers on the planations of Srilanka.

10. Spiro ME. The psychological function of witchcraft belief: The Burmese care, in Candill W, Lin T (eds): Mental Health Research in Asia and Pacific. Honolulu East West Center Press, 1969.

11. Chakraborty A. An Analysis of paranoid symptomatology Indian J of Psychiatry 1964;6:172184.

12. Influence of Magico- Religious belief on psychopathology and pathway to care among patients with manic episode, presenting in psychiatric services at BPKIHS. Nidesh Sapkota, Shyangwa PM, Shakya R. MD thesis. 2007

13. Upadhya K D. Traditional Healers and Faith Healing of Nepal.Souvenir, National CME of PAN, 2007,4-8

14. Psychiatry in South East Asia British Journal of Psychiatry, 123,257-259

15. Abioden OA (1999), University of Ilorin, Nigeria pathway to mental health care in Nigeria. Medline

16. Bagadia VN, Shah LP, Pradhan PV, Gada MT. Treatment of mental disorders in India. Progress in Neuropsychopharmacology. 1979;3:109-18. [P 